\begin{tabular}{l|l|l||c|}
$\begin{array}{l}\text { Journal of } \\
\text { Endocrinology }\end{array}$ & M Toral et al. & $\begin{array}{l}\text { Thyroid hormones and } \\
\text { L-arginine transport }\end{array}$ & $\mathbf{2 3 9 : 1}$
\end{tabular}

\title{
Thyroid hormones stimulate L-arginine transport in human endothelial cells
}

\author{
Marta Toral1, Rosario Jimenez,,2, Sebastián Montoro-Molina3, Miguel Romero',2, Rosemary Wangensteen³, \\ Juan Duarte1,2 and Félix Vargas ${ }^{2,4}$ \\ 1Departamento de Farmacología, Facultad de Farmacia, Granada, Spain \\ 2Instituto de Investigación Biosanitaria GRANADA, Hospitales Universitarios de Granada, Universidad de Granada, Granada, Spain \\ 3Departamento de Ciencias de la Salud, Universidad de Jaén, Jaén, Spain \\ ${ }^{4}$ Departamento de Fisiología, Facultad de Medicina, Granada, Spain \\ Correspondence should be addressed to J Duarte: jmduarte@ugr.es
}

\section{Abstract}

Thyroid hormone activity is associated with L-arginine metabolism and nitric oxide (NO) production, which participate in the cardiovascular manifestations of thyroid disorders. L-arginine transporters play an important role in activating L-arginine uptake and NO production. However, the effects of thyroid hormones on L-arginine transporters in endothelial cells have not yet been evaluated. The following methods were used. We measured L-arginine uptake, mRNA expression of L-arginine transporters, endothelial nitric oxide synthase (eNOS) mRNA and NO generation after the administration of $T_{3}, T_{4}$ and the $T_{3}$ analog, 3,3',5-triiodothyroacetic acid TRIAC in human umbilical vein endothelial cells (HUVECs). We also analyzed the role of $\alpha v \beta 3$ integrin and of phosphatidyl-inositol-3 kinase (PI3K), mitogen-activated protein kinases (MAPKs: ERK1/2, p38 and SAPK-JNK) and intracellular calcium signaling pathways as underlying mechanisms. To this end, $\alpha \mathrm{v} \beta 3$ integrin was pharmacologically inhibited by tetraiodothyroacetic acid (TETRAC) or genetically blocked by silencing $\alpha \mathrm{V}$ mRNA and PI3K, MAPKs and intracellular calcium by selective inhibitors. The following results were obtained. Thyroid hormones and the $T_{3}$ analog TRIAC increased L-arginine uptake in HUVECs, the sodium-independent $y^{+} / C A T$ isoforms, except CAT2b, sodium-dependent $y^{+} L$ system and sodium-independent system $b^{0,+L-a r g i n i n e ~ t r a n s p o r t e r s, ~ e N O S ~ m R N A ~ a n d ~ N O ~}$ production. These effects were suppressed by $\alpha \mathrm{V} \beta 3$ integrin inhibition with TETRAC or $\alpha \mathrm{V}$ integrin downregulation or by $\mathrm{PI}$ K, MAPK or intracellular $\mathrm{Ca}^{2+}$ signaling inhibitors. In conclusion, we report for the first time that activation of L-arginine uptake by thyroid hormones is related to an upregulation of L-arginine transporters. This effect seems to be mediated by activation of $\alpha \mathrm{V} \beta 3$ integrin receptor and subsequent PI3K, MAPK and intracellular $\mathrm{Ca}^{2+}$ signaling pathways.

\author{
Key Words \\ - thyroid hormones \\ - tRIAC \\ - TETRAC \\ - L-arginine transporters \\ - HUVECS \\ - $\alpha \mathrm{v} \beta 3$ integrin \\ - PI3K \\ - MAPK
}

Journal of Endocrinology (2018) 239, 49-62

\section{Introduction}

L-arginine transporters are expressed in endothelial and epithelial cells and play a major role in activating L-arginine transport and nitric oxide (NO) synthesis, which regulates vascular tone and, therefore, arterial pressure (Pallone \& Mattson 2002, Kakoki et al. 2004). The total intracellular concentration of L-arginine in endothelial cells is saturating for endothelial nitric oxide synthase (eNOS) and is consequently not limiting 
for NO production (Block et al. 1995), and it has been reported that cellular L-arginine transport may be more important than intracellular L-arginine levels for NO production (McDonald et al. 1997). Thus, the supply of L-arginine may become limiting and reduce NO formation in physiological and pathological states. In this context, endothelial dysfunction can be improved by the administration of L-arginine in many diseases, including hypertension, atherosclerosis, hyperglycemia, restenosis/ postcoronary angioplasty and reperfusion injury (Creager et al. 1990, Chen \& Sanders 1991, Harrison 1991, Weyrich et al. 1992, Wascher et al. 1997). The cellular uptake of L-arginine is mediated by carrier-mediated transporters and passive diffusion. The saturable transport is produced by $\mathrm{Na}^{+}$-independent transporters (system $\mathrm{y}^{+}, \mathrm{B}^{0,+}$ ) and a $\mathrm{Na}^{+}$-dependent active transporter system, $\mathrm{y}^{+} \mathrm{L}$ (Closs 2002, Mann et al. 2003). System $\mathrm{y}^{+}$, composed of the cationic amino acid transporter (CAT) family of proteins (CAT-1, CAT-2A, CAT-2B, CAT-3 and CAT-4), is the major cationic amino acid transport system and accounts for $\sim 60 \%$ of the transport of the intracellular supply of L-arginine for NOS (Verrey et al. 2004).

Thyroid hormone excess is associated with a hyperdynamic circulation, which is characterized by increased cardiac output, heart rate and pulse pressure and decreased peripheral resistance (Klein 1990, Vargas et al. 2006). Thyroxine generates a concentration-related blood pressure (BP) elevation in rodents (Moreno et al. 2005, Vargas et al. 2006), increases NOS activity in tissues responsible for BP control (Quesada et al. 2002), raises plasma nitrite/nitrate levels (Rodríguez-Gómez et al. 2003), and preserves vascular endothelial function (Vargas et al. 1995). In vitro, $\mathrm{T}_{3}$ augmented eNOS activity in endothelial cells (Hiroi et al. 2006). BP was increased in thyroxine-treated rats by oral treatment with the nonspecific NO inhibitor $N^{\omega}$-nitro-L-arginine methyl ester (L-NAME) and the iNOS inhibitor aminoguanidine, administered at concentrations without pressor effects in normal rats (Rodríguez-Gómez et al. 2003, 2005). Our group also reported that thyroid hormone levels modulate different L-arginine metabolic pathways and that changes in the abundance of eNOS and arginases I and II proteins in renal and cardiovascular tissues may be related to the hemodynamic and renal manifestations of thyroid disorders (Rodríguez-Gómez et al. 2016). Thus, chronic arginase inhibition with N[omega]-hydroxy-nor-Larginine (nor-NOHA) prevented the increased systolic BP and heart rate and decreased proteinuria in hyperthyroid rats (Rodríguez-Gómez et al. 2015). All these observations support an association of thyroid hormone activity with L-arginine metabolism and NO production.

L-arginine transport is regulated by NO donors (Ogonowski et al. 2000), NOS agonists (Bogle et al. 1991), inflammatory factors (Simmons et al. 1996), cellular membrane potential (Zharikov et al. 1997), free radicals (Patel et al. 1996) and pharmacological and vasoactive agents (Bogle et al. 1991, Grupper et al. 2013). It is affected in several diseases, including acute and chronic kidney diseases (Schwartz et al. 2002, Martens et al. 2014), intrauterine growth retardation (Casanello et al. 2009, Grupper et al. 2013), diabetes (Simmons et al. 1996) or obesity (Rajapakse et al. 2014). Hormones such as insulin (González et al. 2011) or collectrin (Malakauskas et al. 2007) also modulate L-arginine transport; however, the role of thyroid hormones has not yet been evaluated, despite their important participation in L-arginine metabolism and in NOS activity and function. Therefore, the objectives of this study were to evaluate the effects of thyroid hormones on L-arginine transporters and other variables in human umbilical vein endothelial cells (HUVECs) and to examine the contributions of $\alpha v \beta 3$ integrin and of phosphatidylinositol-3 kinase (PI3K), mitogen-activated protein kinase (MAPK) and intracellular calcium mobilization signaling pathways as underlying mechanisms.

\section{Material and methods}

\section{Culture of HUVECs}

Endothelial cells were isolated from human umbilical cord veins using a previously reported method with some modifications (Jiménez et al. 2010). Cells were cultured in medium 199 supplemented with 20\% FBS, $2 \mathrm{mM}$ penicillin/streptomycin, $2 \mathrm{mM}$ amphotericin $\mathrm{B}$, $2 \mathrm{mM}$ glutamine, $10 \mathrm{mM}$ HEPES, $30 \mu \mathrm{g} / \mathrm{mL}$ endothelial cell growth supplement and $100 \mathrm{mg} / \mathrm{mL}$ heparin in a humidified $5 \% \mathrm{CO}_{2}$ atmosphere at $37^{\circ} \mathrm{C}$. All cells used in experiments from passages 2 to 5 were previously starved in serum-free medium for $2 \mathrm{~h}$.

HUVECs were incubated with a vehicle control (final concentration of $0.04 \mathrm{~N} \mathrm{NaOH}$ ), the thyroid hormone 3,3',5-triiodo-L-thyronine $\left(\mathrm{T}_{3}, 10 \mathrm{nM}\right.$ and $100 \mathrm{nM}$ ), L-thyroxine $\left(\mathrm{T}_{4}, 10 \mathrm{nM}\right.$ and $100 \mathrm{nM}$ ) (diluted to its final concentration from $10^{-3} \mathrm{M}$ stock, using the vehicle as diluent) and thyroid hormone analogue 3,3',5-triiodothyroacetic acid (TRIAC, $10 \mathrm{nM}$ and $100 \mathrm{nM}$ ), for 2 and $6 \mathrm{~h}$. In some experiments, cells were co-incubated with thyroid hormones and tetraiodothyroacetic acid 
(TETRAC, $100 \mathrm{nM}$ ), a $\alpha \mathrm{v} \beta 3$ blocker that inhibits binding of thyroid hormones to the plasmatic membrane (36), as well as with TETRAC alone. HUVECs were also co-incubated with $\mathrm{T}_{3}(100 \mathrm{nM})$ for $6 \mathrm{~h}$ and PD98059 $(10 \mu \mathrm{M}, \mathrm{ERK} 1 / 2$ inhibitor, Calbiochem, Darmstadt, Germany), SB203580 $(10 \mu \mathrm{M}$, p38 MAPK inhibitor, Calbiochem), SP600125 $(25 \mu \mathrm{M}$, SAPK-JNK inhibitor, Calbiochem), the PI3K inhibitor LY-294002 $(1 \mu \mathrm{M})$ (all these inhibitors were diluted with DMSO, which was added to control cells) or 1,2-bis(2-aminophenoxy)ethane-N,N, $\mathrm{N}^{\prime}, \mathrm{N}^{\prime}$-tetraacetic acid tetrakis (acetoxymethylester) (BAPTA/AM) a selective chelator of intracellular $\mathrm{Ca}^{2+}$ stores, added $1 \mathrm{~h}$ before $\mathrm{T}_{3}$ administration. The effects of these inhibitors without $\mathrm{T}_{3}$ were also analyzed. HUVECs were incubated in medium supplemented with 1\% FBS in all experiments. Cells were then used to characterize the L-arginine transport system and gene expression.

\section{Characterization of L-arginine transport system in HUVECs}

Confluent cultures of HUVECs were prepared in 6-well plates. To determine the transporters for L-arginine supplied to the cells, HUVECs were incubated in an uptake buffer (in mM: $25 \mathrm{HEPES}, 1.8 \mathrm{CaCl}_{2}, 5.4 \mathrm{KCl}, 140$ choline chloride, $0.8 \mathrm{MgSO}_{4}$ and 5 glucose) containing $20 \mathrm{nM} \mathrm{L}-\left[{ }^{3} \mathrm{H}\right]$ arginine for periods of $0 \mathrm{~min}, 2$ and $6 \mathrm{~h}$. In some experiments, $50 \mu \mathrm{M}$ of unlabeled L-arginine was included in the solution to determine that the transporters measured were the expected. L-arginine uptake was stopped by addition of ice-cold uptake buffer, and cells were washed three times with $1 \mathrm{~mL}$ of this buffer. After the final wash, cells were lysed by addition of $125 \mu \mathrm{L}$ $0.5 \%$ SDS in $0.1 \mathrm{~N} \mathrm{NaOH}$. Cellular lysates were added to $4 \mathrm{~mL}$ of Ecoscint-A scintillation fluid, and scintillation spectroscopy (Beckman Instruments) was used to determine the amount of $\mathrm{L}-\left[{ }^{3} \mathrm{H}\right]$ arginine, considered to represent the cellular transport of L-arginine as previously described (Ogonowski et al. 2000).

\section{RT-PCR analysis}

For RT-PCR analysis, total RNA was extracted from HUVEC by homogenization and converted to cDNA using standard methods. PCR was performed with a Techne Techgenethermocycler (Techne, Cambridge, UK). Quantitative real-time RT-PCR was applied to analyze mRNA expression, and the sequences of sense and antisense primers used for amplification are reported in Table 1. Preliminary experiments were carried out with various amounts of cDNA to determine non-saturating conditions of PCR amplification for all genes studied. Under these conditions, the relative quantification of mRNA was assessed by the SYBR Green based-RTPCR method. The efficiency of the PCR reaction was determined by using a dilution series of a standard tissue sample. Quantification was performed with the $\Delta \Delta \mathrm{Ct}$ method. The housekeeping genes $\beta$-actin was used for internal normalization.

\section{Transfection of $\alpha v \beta 3$ siRNAs}

Confluent HUVECs were transfected with $\alpha \mathrm{v}$-specific siRNA (pooled, validated siRNA from Dharmacon, Lafayette, CO, USA) or a scrambled siRNA to serve as a negative control, using Lipofectamine RNAiMAX (Invitrogen Life Technologies) for $48 \mathrm{~h}$, as previously described (Quintela et al. 2014).

\section{Quantification of NO released by DAF=2}

NO released by HUVECs was quantified with the NO-sensitive fluorescent probe diaminofluorescein-2 (DAF-2), as previously reported (Quintela et al. 2014). Briefly, cells were incubated as described earlier. After this period, TH-treated and un-treated cells were washed with PBS and pre-incubated with L-arginine $(100 \mu \mathrm{M}$ in PBS, $\left.5 \mathrm{~min}, 37^{\circ} \mathrm{C}\right)$. Next, DAF-2 $(0.1 \mu \mathrm{M})$ was incubated for $2 \mathrm{~min}$, and the calcium ionophore calimycin (A23187, $1 \mu \mathrm{M})$ was then added for $30 \mathrm{~min}$, followed by measurement of the fluorescence intensity (arbitrary units, AU) with a spectrofluorimeter (Fluorostart, BMG Lab technologies, Offenburg, Germany). The autofluorescence was subtracted from each value. In some experiments, L-NAME $(100 \mu \mathrm{M})$ was added $15 \mathrm{~min}$ before the addition of L-arginine. The difference between the fluorescence signal without and with L-NAME was considered as the NO production.

\section{Western blotting analysis}

Cells underwent the siRNA procedure for $48 \mathrm{~h}$ followed by Western blotting, running HUVEC homogenates on a SDS-PAGE ( $40 \mu \mathrm{g}$ of protein per lane) and then transferring the proteins to PVDF membranes. $\alpha \mathrm{V}$ was detected after incubating the membranes with rabbit polyclonal antihuman integrin $\alpha \mathrm{v}$ (Abcam) overnight at $4^{\circ} \mathrm{C}$ with the secondary peroxidase conjugated antibodies. Antibody binding was detected with an ECL system (Amersham Pharmacia Biotech, Amersham, UK), and densitometric 
Table 1 Oligonucleotides for real-time RT-PCR.

\begin{tabular}{l} 
mRNA targets \\
\hline CAT-1 \\
CAT-2a \\
CAT-2b \\
CAT-4 \\
$y^{+}$LAT1 \\
$y^{+}$LAT2 \\
$B^{0,+}+$ System \\
$\alpha V$ \\
eNOS \\
Actb
\end{tabular}

Descriptions
Cationic amino acid transporter-1
Cationic amino acid transporter-2a
Cationic amino acid transporter-2b
Cationic amino acid transporter- 4
System $\mathrm{y}^{+} \mathrm{L}$ transport 1
System $\mathrm{y}^{+} \mathrm{L}$ transport 2
System $\mathrm{B}^{0,+}$
Alpha- $\mathrm{V}$
Endothelial nitric oxide synthase
Beta actin

analysis was performed using Scion Image-Release Beta 4.02 software (http://www.scioncorp.com). $\alpha \mathrm{v} / \beta$ actin abundance ratios were calculated and expressed as a percentage of the values in control cells from the same gel.

\section{Reagents}

All chemicals were obtained from Sigma-Aldrich unless otherwise stated.

\section{Statistical analysis}

Results were expressed as means \pm s.E.M. Statistical analyses were performed using Graph Pad Prism 5 software. A two-factor ANOVA was used to test for drug or group interactions. When a significant interaction was detected, individual differences between groups were discerned by one-way ANOVA with Student-Newman-Keuls' post hoc test. Significance was accepted at $P<0.05$.

\section{Results}

\section{Thyroid hormones stimulated $L-\left[{ }^{3} \mathrm{H}\right]$ arginine uptake} in HUVECs

Given that cellular L-arginine transport is very important for NO production, the effects of both thyroid hormones ( $\mathrm{T}_{3}$ and $\mathrm{T}_{4}$ at 10 and $100 \mathrm{nM}$ concentrations) on L-arginine uptake were analyzed after $0 \mathrm{~min}, 2$ and $6 \mathrm{~h}$ after hormone administration to HUVECs (Fig. 1A and $\mathrm{B})$. L-arginine transport was significantly stimulated by $\mathrm{T}_{3}$ at $2 \mathrm{~h}$ with the $100 \mathrm{nM}$ concentration and at $6 \mathrm{~h}$ with both 10 and $100 \mathrm{nM}$ concentrations. $\mathrm{T}_{4}$ increased L-arginine uptake at $2 \mathrm{~h}$ with both concentrations, but the slight increase observed at $6 \mathrm{~h}$ did not reached statistical signification.

\begin{tabular}{|lr} 
http://joe.endocrinology-journals.org & ○ 2018 Society for Endocrinology \\
https://doi.org/10.1530/JOE-18-0229 & Published by Bioscientifica Ltd. \\
Printed in Great Britain
\end{tabular}

Sense
ATCTGCTTCATCGCCTACTT
TTCTCGTCCTTCTGTTTGTG
TTTTCCCAATGCCTCGTGTA
ATGGTGGGCTCGGGTCTCTA
CTTTGGTCTCTCTCTGGTCA
CCTACCATCTTGTCCCTAAC
GTCTTCTTCTGGCTTGGCTCATA
GCGGCGGAAAAGCCATCG
GTGGACGCACAGTAACATGG
CGGTGAAGGTGACAGCAG

\section{Antisense}

TCTCTGCCTCTGGTAAAAAC TTTGGGCTGGTCGTAAGATA CATTTGGGCTGGTCGTAAGA TGCGGATGCTGTGGCTGAAC GCTTATGTTCTGGCACTCTG TTTCTGGGTTTTTGATTTCT CAATCATACACCAGCCTAAAGCA CGCCGCCTTTTCGGTAGC ACCTCCCAGTTCTTCACACG TGTGTGGACTTGGGAGAGG

Effects of thyroid hormones on the $\mathrm{Na}^{+}$-independent transporter (system $y^{+}$) CAT-1, CAT-2a, CAT-2b and CAT-4

After observing that thyroid hormones increased L-arginine uptake in HUVECs, we examined the influence of thyroid hormones on the main family of L-arginine transporters in endothelial cells, the $\mathrm{Na}^{+}$-independent transporter system $\mathrm{y}^{+}$. The effects of 10 and $100 \mathrm{nM}$ of $\mathrm{T}_{3}$ and $\mathrm{T}_{4}$ on the expression of system $\mathrm{y}^{+}$were evaluated after 2 and $6 \mathrm{~h}$ in HUVECs. CAT- 1 mRNA was augmented after $6 \mathrm{~h}$ of administration with either thyroid hormone at the higher concentration, while no significant effects were observed after incubation with either hormone (Fig. 2A).
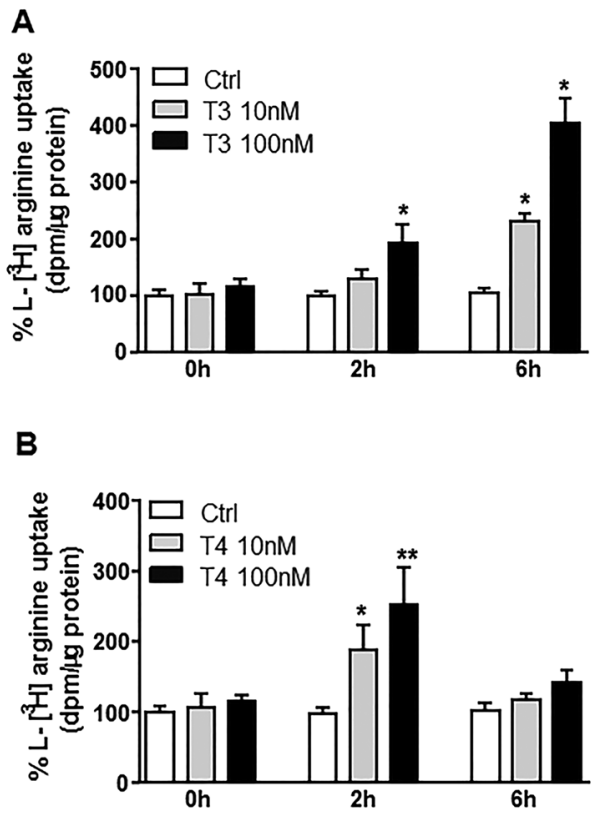

\section{Figure 1}

Effects of thyroid hormones on L-arginine uptake. HUVEC monolayers were incubated with uptake buffer containing $20 \mathrm{nM} \mathrm{L-}\left[{ }^{3} \mathrm{H}\right]$ arginine for 0,2 or $6 \mathrm{~h}$ in the absence or presence of $\mathrm{T}_{3}(\mathrm{~A})$ or $\mathrm{T}_{4}(\mathrm{~B})$ at concentrations of 10 or $100 \mathrm{nM}$ ( $n=6-8$ for each concentration or time). The amount of $\mathrm{L}-\left[{ }^{3} \mathrm{H}\right]$ arginine taken up by cells over time was determined as described in materials and methods. Data are expressed as means \pm s.E.M. ${ }^{*} P<0.05$, $* * P<0.01$ vs control (Ctrl) levels. 


\begin{tabular}{l|l|l|c|c|}
$\begin{array}{l}\text { Journal of } \\
\text { Endocrinology }\end{array}$ & M Toral et al. & $\begin{array}{l}\text { Thyroid hormones and } \\
\text { L-arginine transport }\end{array}$ & $\mathbf{2 3 9 : 1}$ \\
\hline
\end{tabular}

A
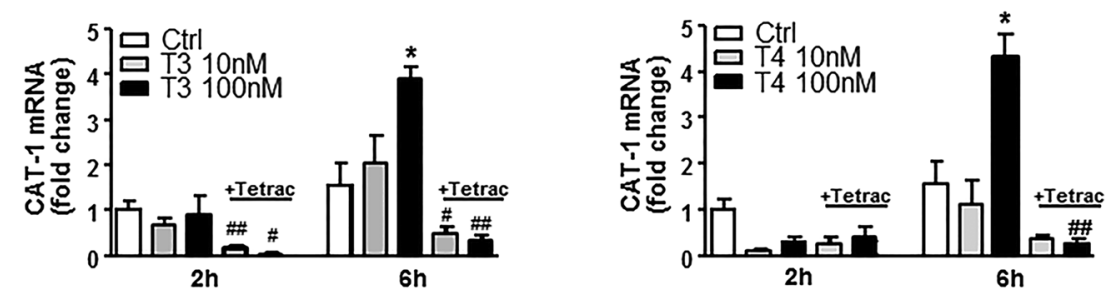

B
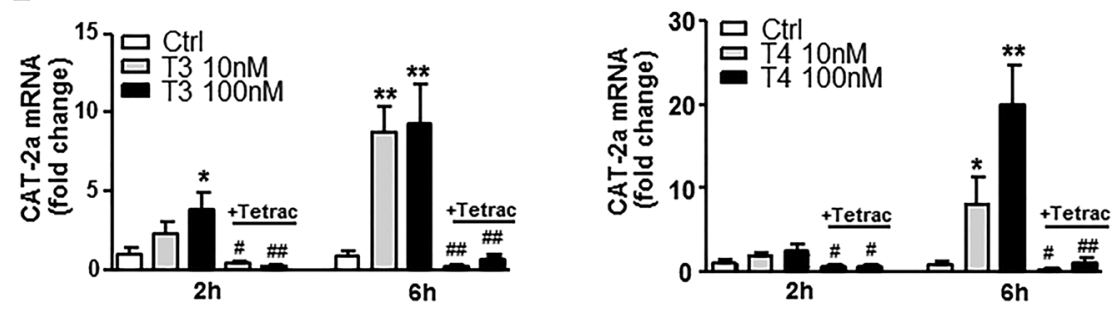

C
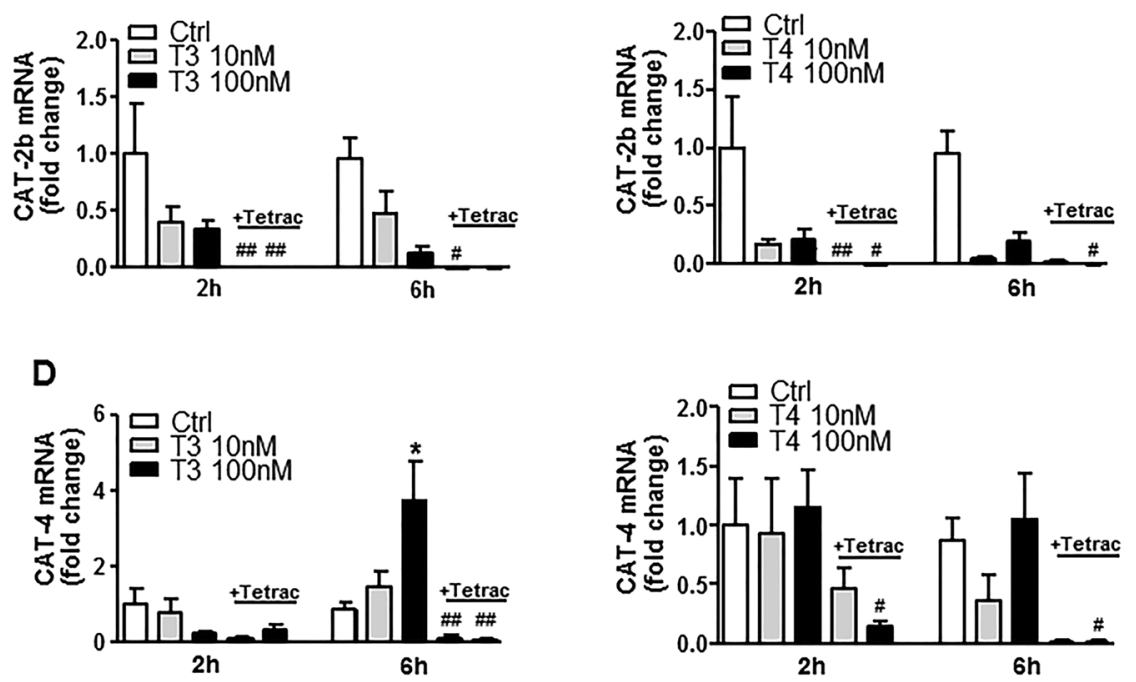

Figure 2

Effects of thyroid hormones on expression of mRNA related to system $\mathrm{y}^{+}$in HUVECs. Cultures were incubated for the indicated times in the presence of $T_{3}$ and $T_{4}$ at concentrations of 10 and $100 \mathrm{nM}$ with or without coincubation with TETRAC $(100 \mathrm{nM})$, before RNA extraction and reverse transcription. Quantitative real-time RT-PCR was applied to analyze mRNA expression, using the housekeeping genes $\beta$-actin for internal normalization. mRNA levels of CAT-1 (A), CAT-2a (B), CAT-2b (C) and CAT-4 (D) after thyroid hormone exposure. The number of cases was 6-7 for each time and concentration. Data are expressed as means \pm S.E.M. ${ }^{*} P<0.05, * * P<0.01$ vs control (Ctrl) levels. $\# P<0.05, \# P<0.01$ vs without TETRAC.

CAT-2a mRNA was augmented by the higher concentration of $\mathrm{T}_{3}$ after $2 \mathrm{~h}$ and by both concentrations of $\mathrm{T}_{3}$ after $6 \mathrm{~h}$ (Fig. 2B). CAT-2a mRNA was increased by both $\mathrm{T}_{4}$ concentrations at $6 \mathrm{~h}$, observing no significant effects at $2 \mathrm{~h}$ (Fig. 2B). CAT-2b mRNA was not increased by either concentrations of $\mathrm{T}_{3}$ or $\mathrm{T}_{4}$ after any time period (Fig. 2C). CAT-4 was only increased by the higher concentration of $\mathrm{T}_{3}$ after $6 \mathrm{~h}$, and no significant change in this transporter was observed with either hormone at other concentrations or times (Fig. 2D).

\section{Effects of thyroid hormones on the $\mathrm{Na}^{+}$-dependent transporter (system $y^{+}$) CATs $y^{+}$LAT1 and $y^{+}$LAT2}

Because both thyroid hormones were found to stimulate system $y$ transporter, we also studied their effects on the
$\mathrm{Na}^{+}$-dependent transporter $\mathrm{y}^{+} \mathrm{L}$ system, which works in additive cooperation with $\mathrm{y}^{+}$system. Both concentrations of $\mathrm{T}_{3}$ increased $\mathrm{y}^{+} \mathrm{LAT} 1 \mathrm{mRNA}$ after $6 \mathrm{~h}$, and the increase was statistically significant with the higher concentration (Fig. 3A). Similar increases were observed with $\mathrm{T}_{4}$ after $2 \mathrm{~h}$ (Fig. 3A). Transporter $y^{+}$LAT2 mRNA was only upregulated by $10 \mathrm{nM} \mathrm{T}_{3}$ after $6 \mathrm{~h}$ (Fig. 3B).

\section{Effects of thyroid hormones on the $\mathrm{Na}^{+}$-independent transporter system Bo,+}

L-arginine transport is also mediated by the CAT system $\mathrm{B}^{0,+}$ in HUVECs, and we therefore analyzed the effects of thyroid hormones on this transporter. Both concentrations of $\mathrm{T}_{3}$ significantly stimulated $\mathrm{B}^{0,+}$ mRNA 
A

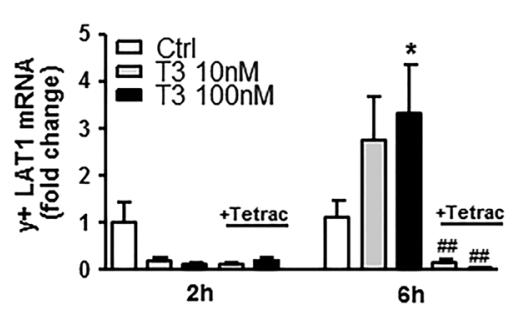

B

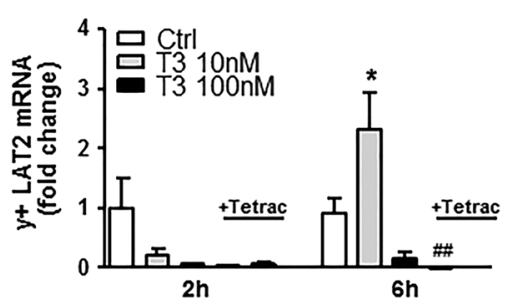

C

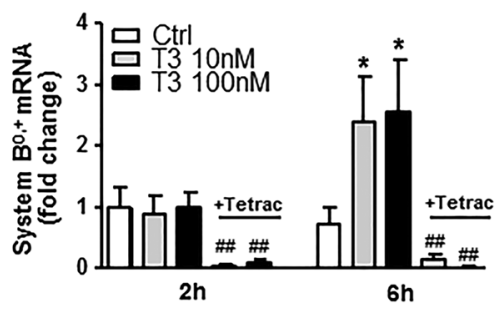

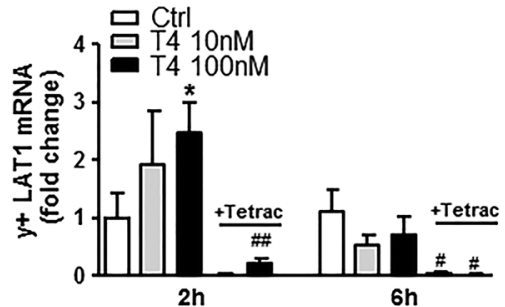
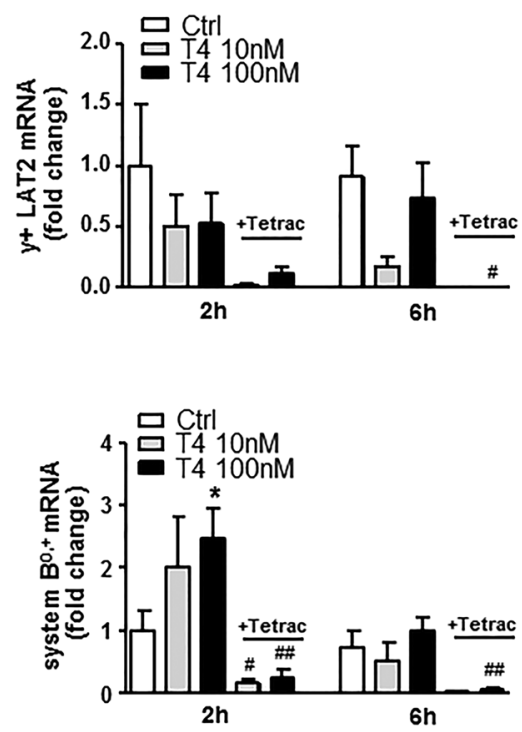

Figure 3

Effect of thyroid hormones on expression of mRNA related to systems $y^{+} L$ and $B^{0,+}$ in HUVECs. Cultures were incubated for the indicated times in the presence of $T_{3}$ and $T_{4}$ at concentrations of 10 and $100 \mathrm{nM}$ with or without coincubation with TETRAC $(100 \mathrm{nM})$, before RNA extraction and reverse transcription. Quantitative real-time RT-PCR was applied to analyze mRNA expression, using the housekeeping genes $\beta$-actin for internal normalization. mRNA levels of $y^{+}$LAT1 (A), $y+$ LAT2 (B) and $\mathrm{B}^{0,+}(\mathrm{C})$ after thyroid hormone exposure. The number of cases was 5-8 for each time and concentration. Data are expressed as means \pm S.E.M. ${ }^{*} P<0.05$ vs control (Ctrl) levels. ${ }^{\#} P<0.05,{ }^{\# \# P<0.01}$ vs without TETRAC. generation after $6 \mathrm{~h}$ (Fig. 3C), and both concentrations of $\mathrm{T}_{4}$ increased the expression of $\mathrm{B}^{0,+}$ mRNA after $2 \mathrm{~h}$, although the increase was only statistically significant at the $100 \mathrm{nM}$ concentration (Fig. 3C).

\section{Effects of TRIAC on L-arginine transporters}

To further evaluate the impact of thyroid hormones on L-arginine transporters, we also explored the effects of TRIAC, a naturally occurring thyroid hormone metabolite that closely resembles the bioactive hormone $\mathrm{T}_{3}$. We analyzed the effects of TRIAC at concentrations of 10 and $100 \mathrm{nM}$ on L-arginine transporters after 2 and $6 \mathrm{~h}$ of exposure. CAT-1 mRNA was significantly increased with the higher concentration after $6 \mathrm{~h}$ (Fig. 4A), CAT-2a mRNA was upregulated by both concentrations after 2 and $6 \mathrm{~h}$ (Fig. 4A), while TRIAC had no effect on CAT-2b at either concentration (Fig. 4A) and CAT-4 was stimulated at $6 \mathrm{~h}$ by the high concentration (Fig. 4A). $\mathrm{y}^{+}$LAT1 mRNA, $\mathrm{y}^{+}$LAT2 mRNA (Fig. 4B) and $\mathrm{B}^{0,+}$ system mRNA were only augmented with the higher concentration after $6 \mathrm{~h}$ (Fig. 4C). Thus, the effects of TRIAC on the different
L-arginine transport systems were similar to those of $\mathrm{T}_{3}$ after 2 and $6 \mathrm{~h}$.

\section{Effects of $T_{3}, T_{4}$ and TRIAC on eNOS mRNA expression and NO production in HUVECs}

Given the key role played by eNOS and NO in cardiovascular and renal functions and their contribution to the cardiac and renal manifestations of thyroid disorders, we studied the effects of $\mathrm{T}_{3}, \mathrm{~T}_{4}$ and TRIAC on eNOS mRNA expression and NO production. Under our experimental conditions, exposure of HUVECs to $\mathrm{T}_{3}$ produced a concentrationrelated increase in eNOS mRNA expression after $6 \mathrm{~h}$ but did not affect this expression after $2 \mathrm{~h}$ (Fig. 5A). However, $\mathrm{T}_{3}$ incubation increased A23187-stimulated NO generation at both 2 and $6 \mathrm{~h}$ with the higher concentration tested (Fig. 5A). In contrast, $\mathrm{T}_{4}$ produced a concentration-related increase in eNOS mRNA after $2 \mathrm{~h}$ but had no effect after $6 \mathrm{~h}$, which correlated with the increased NO generation found at this time (Fig. 5B). As observed for $\mathrm{T}_{3}$ and the $\mathrm{T}_{3}$ thyroid hormone analogue, TRIAC increased eNOS mRNA expression with the higher concentration after $6 \mathrm{~h}$, 
A
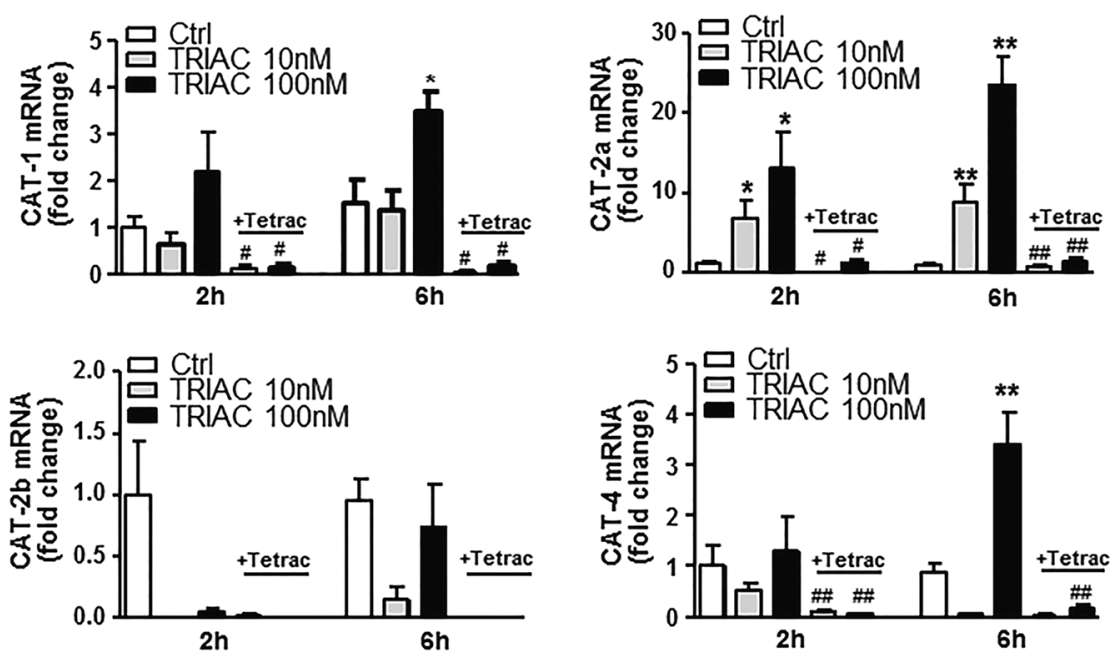

B
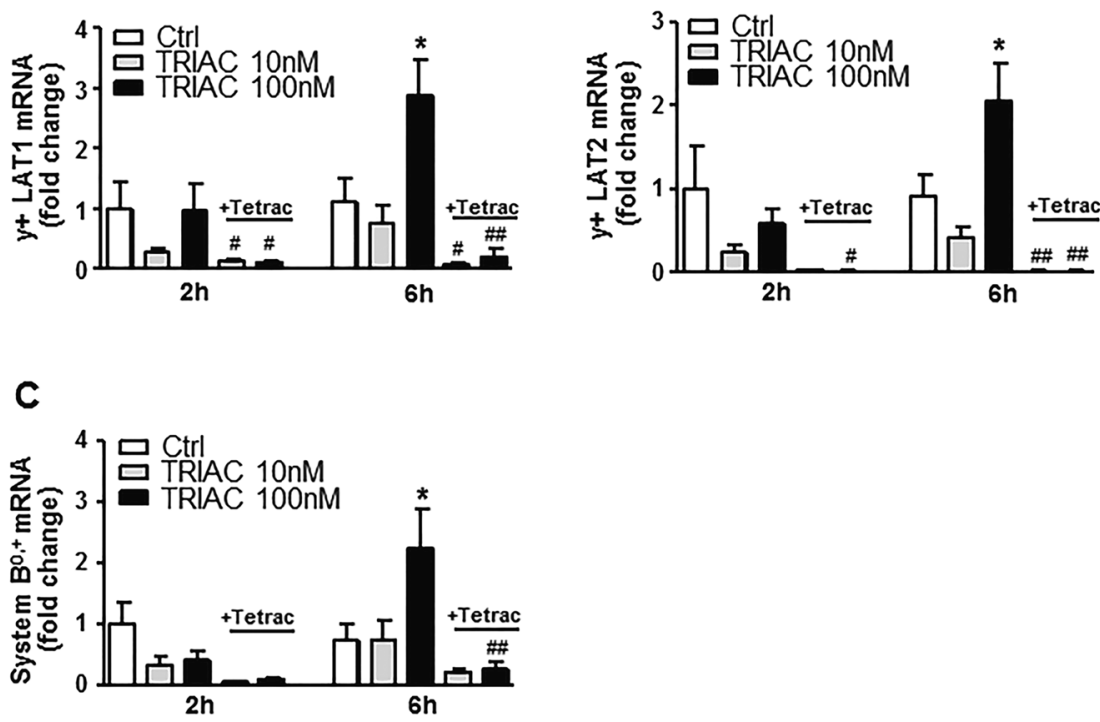

Figure 4

Effects of TRIAC on L-arginine transporters. Cultures were incubated for the indicated times in the presence of TRIAC at concentrations of 10 and $100 \mathrm{nM}$ with or without coincubation with TETRAC (100 nM) before RNA extraction and reverse transcription. The methods were the same as for the natural thyroid hormones. mRNA levels of CAT-1, CAT-2a, CAT-2b and CAT-4 (A), $y+$ LAT1, and $\mathrm{y}+\mathrm{LAT2}(\mathrm{B})$ and $\mathrm{B}^{0,+}$ (C) after TRIAC exposure. The number of cases was 5-8 for each time and concentration. Data are expressed as means \pm S.E.M. $* P<0.05, * * P<0.01$ vs control (Ctrl) levels. ${ }^{\#} P<0.05,{ }^{\#} P<0.01$ vs without TETRAC.

but increased A23187-stimulated NO production at both times (Fig. 5C).

\section{Pharmacological blockade of $\alpha \mathrm{v} \beta 3$ integrin with TETRAC suppresses L-arginine transporters, eNOS expression and NO generation in HUVECs}

$\mathrm{T}_{4}$ and $\mathrm{T}_{3}$ activate the cell-surface receptor for thyroid hormone on a plasma membrane structural protein, integrin $\alpha v \beta 3$, which is known to mediate local actions of the hormone on membrane ion pumps and the transport of chemotherapeutic agents and amino acids. We therefore investigated whether this membrane receptor can be used to stimulate the mRNA expression of L-arginine transporters by thyroid hormones, using the integrin $\alpha v \beta 3$ thyroid hormone receptor blocker TETRAC. Coincubation of TETRAC with $\mathrm{T}_{3}, \mathrm{~T}_{4}$ or TRIAC suppressed the stimulating effects of these agents on the different L-arginine transporters after 2 and $6 \mathrm{~h}$ of incubation (Figs 2 , and 4). TETRAC also suppressed the stimulating effects of $\mathrm{T}_{3}, \mathrm{~T}_{4}$ and TRIAC on eNOS mRNA expression (Fig. 5A, B and $\mathrm{C})$. NO production stimulated by $\mathrm{T}_{4}, \mathrm{~T}_{3}$ or its analog TRIAC was also suppressed by TETRAC (Fig. 5A, B and C). TETRAC administration did not have significant effect in control conditions (Supplementary Fig. 1, see section on supplementary data given at the end of this article). 


\begin{tabular}{l|l|l|c|c|} 
Journal of & M Toral et al. & $\begin{array}{l}\text { Thyroid hormones and } \\
\text { L-arginine transport }\end{array}$ & $\mathbf{2 3 9 : 1}$ & $\mathbf{5 6}$ \\
Endocrinology & &
\end{tabular}

A
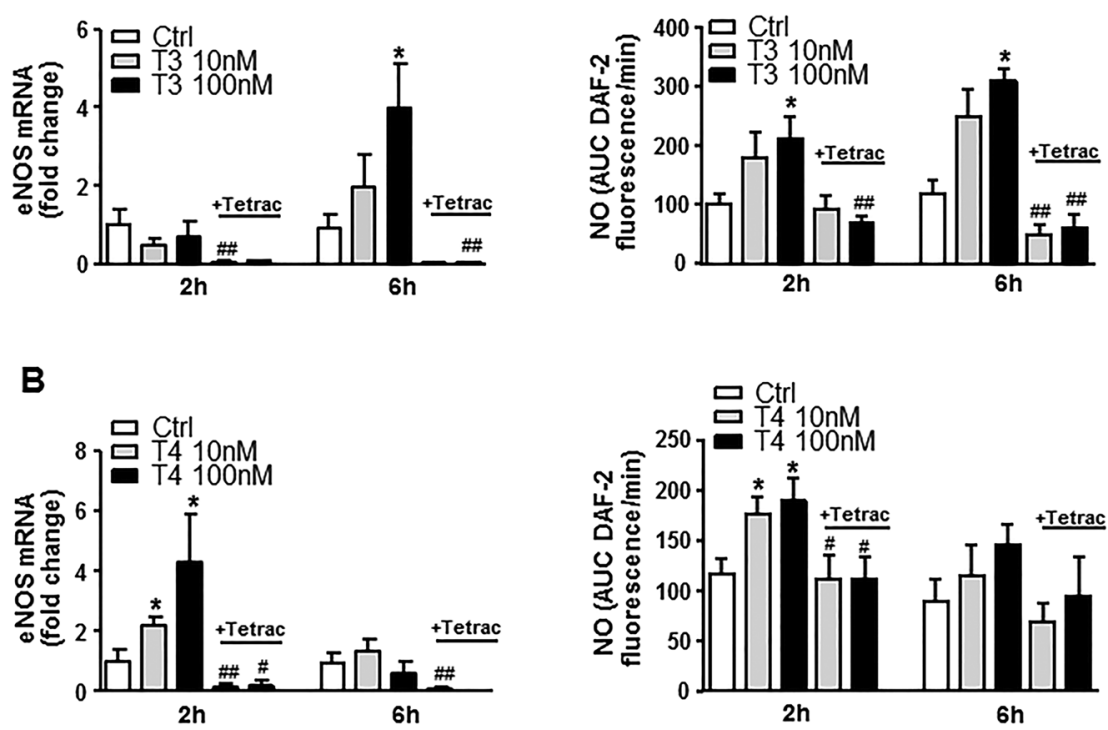

Figure 5

Effects of $\mathrm{T}_{3}, \mathrm{~T}_{4}$ and TRIAC on eNOS mRNA expression and NO production in HUVECs.

Cultures were incubated for the indicated times in the presence $T_{3}, T_{4}$ and TRIAC at concentrations of 10 and $100 \mathrm{nM}$ with or without coincubation with TETRAC (100 nM) before RNA extraction and reverse transcription. Quantitative real-time RT-PCR was applied to analyze mRNA expression, using the housekeeping genes $\beta$-actin for internal normalization. Expression of eNOS mRNA was measured using the same experimental procedure as for the L-arginine transporters. eNOS mRNA after exposure to $T_{3}(A), T_{4}(B)$ or TRIAC (C).
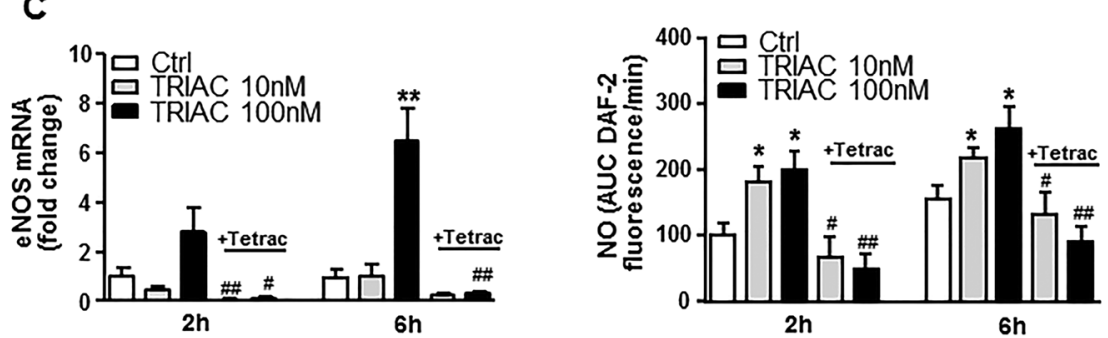
A23187-stimulated NO production was measured with the NO-sensitive fluorescent probe diaminofluorescein-2 (DAF-2). After the exposure to $\mathrm{T}_{3}(A), T_{4}(B)$ or TRIAC (C), TH-treated and un-treated cells were washed with PBS before of A23187 addition. Data are expressed as means \pm S.E.M. ${ }^{*} P<0.05,{ }^{*} P<0.01$ vs control (Ctrl) levels. $\left.{ }^{P}\right)<0.05, \# \#<0.01$ vs without TETRAC $(n=5-8)$.

\section{Genetic blockade of $\alpha v \beta 3$ integrin suppresses \\ L-arginine uptake, L-arginine transporters upregulation, eNOS mRNA and nitric oxide production induced by $\mathrm{T}_{3}$ in HUVECS}

The above observations were verified by conducting another set of experiments in which HUVECs were treated with control or $\alpha v$-specific siRNA. At $48 \mathrm{~h}$ after transfection with $\alpha v$-specific siRNA, HUVECs showed a $\approx 90 \%$ decrease in $\alpha \mathrm{V}$ mRNA and protein with respect to control siRNAtreated cells (Fig. 6A).

$\alpha \mathrm{V}$ siRNA suppressed the stimulating effects of $100 \mathrm{nM} \mathrm{T}_{3}$ on L-arginine uptake (Fig. 6B) and on the different L-arginine transporters (Fig. 6C) as well as on eNOS mRNA (Fig. 6D) and nitric oxide generation (Fig. 6E) after $6 \mathrm{~h}$ of incubation. These results are consistent with those obtained by the pharmacological blockade of $\alpha \mathrm{v} \beta 3$ with TETRAC. The agonist $\left(\mathrm{T}_{3}\right)$, concentration $(100 \mathrm{nM})$, and incubation time $(6 \mathrm{~h})$ were selected as providing the most effective stimulus in the previous experiments.

http://joe.endocrinology-journals.org https://doi.org/10.1530/JOE-18-0229 (c) 2018 Society for Endocrinology Published by Bioscientifica Ltd. Printed in Great Britain
PI3K and MAPK inhibitors and chelation of intracellular $\mathrm{Ca}^{2+}$ suppress L-arginine transporters upregulation, eNOS mRNA and nitric oxide production stimulated by $\mathrm{T}_{3}$ in HUVECS

Several thyroid hormone-stimulated membrane transport systems are activated through transduction pathways involving PI3K, MAPK and intracellular calcium. We therefore explored the possible involvement of these intracellular signaling pathways in the stimulatory effects of thyroid hormones on L-arginine transporters. For this purpose, we examined the effect of the PI3K inhibitor, LY-294002 on the stimulating effects of $100 \mathrm{nM} \mathrm{T}_{3}$ on the different L-arginine transporters after $6 \mathrm{~h}$ of incubation. As shown in Fig. 7A, B and C, PI3K inhibition suppressed the mRNA expression of all L-arginine transporters studied. We also explored the role of the MAPK pathway by analyzing the impact of the ERK1/2 inhibitor PD98059, JNK inhibitor SP600125 and p38 MAPK inhibitor SB203580 on the stimulating effects of $100 \mathrm{nM} \mathrm{T}_{3}$. All three compounds inhibited the stimulating effect of $\mathrm{T}_{3}$ 


\begin{tabular}{l|l|l|l|l|}
$\begin{array}{l}\text { Journal of } \\
\text { Endocrinology }\end{array}$ & M Toral et al. & $\begin{array}{l}\text { Thyroid hormones and } \\
\text { L-arginine transport }\end{array}$ & $\mathbf{2 3 9 : 1}$ \\
\hline
\end{tabular}

A

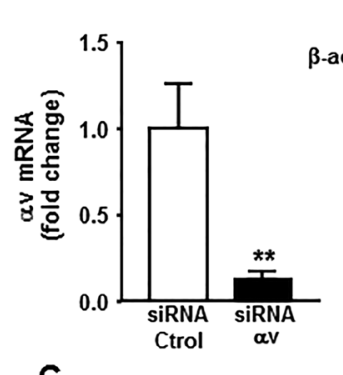

C
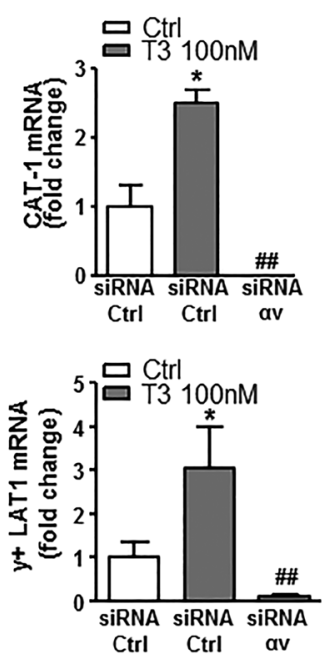

D

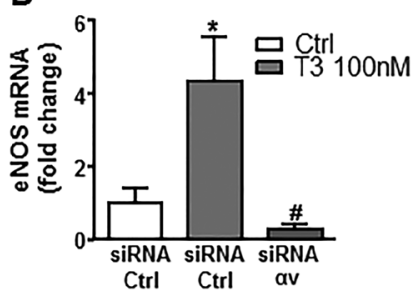

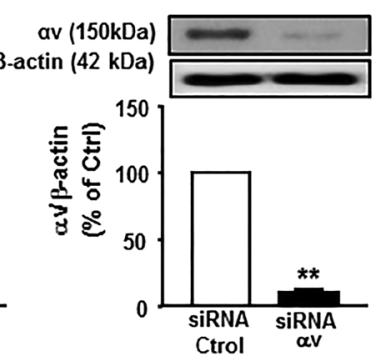

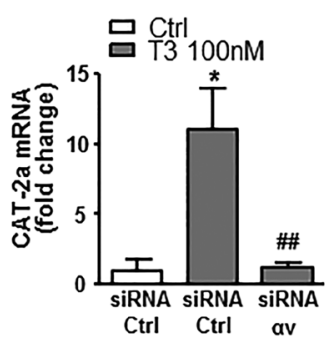

B
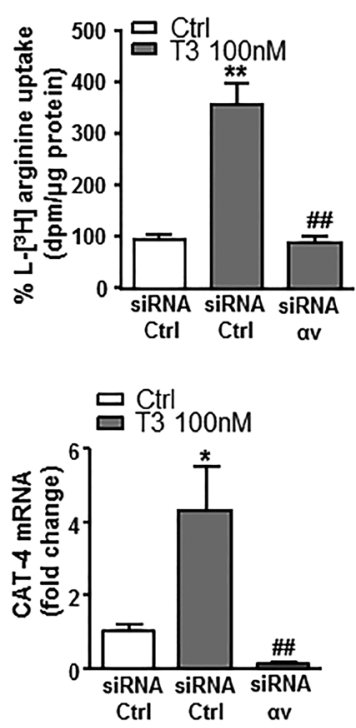

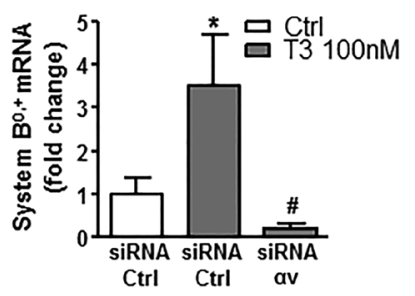

Figure 6

Effects of genetic blockade of $\alpha \vee \beta 3$ integrin on L-arginine uptake, mRNA level of all L-arginine transporters, and NO production stimulated by $\mathrm{T}_{3}$ $(100 \mathrm{nM})$. Confluent HUVECs were transfected with control (Ctrl) or av-specific siRNA (using Lipofectamine RNAiMAX). (A) mRNA and protein levels of $\alpha v$ after $48 \mathrm{~h}$ of si-RNA transfection. Data are expressed as means \pm S.E.M. $(n=5-8) .{ }^{*} P<0.05$, $* * P<0.01$ vs siRNA-Ctrl. L-[ $\left.{ }^{3} \mathrm{H}\right]$ arginine uptake (B), mRNA levels of CAT-1, CAT-2a, and CAT-4, $y+$ LAT1, system $B^{0,+}(C)$, and eNOS (D), and A23187-

stimulated NO production (E) before and after $6 \mathrm{~h}$ of T3 incubation (100 nM) in siRNA-Ctrl or siRNA- $\alpha$ v transfected HUVECs. Data are expressed as means \pm s.E.M. ${ }^{*} P<0.05, * * P<0.01$ vs siRNA-Ctrl; $\# P<0.05, \# P<0.01$ vs $T_{3}$ siRNA-Ctrl.

on the mRNA expression of all L-arginine transporters analyzed (Fig. 7A, B and C). Seemingly, PI3K and MAPK blockers also inhibited eNOS mRNA (Fig. 7D) and nitric oxide generation (Fig. 7E) stimulated by $\mathrm{T}_{3}$. However, the administration of these inhibitors did not have significant effect in control conditions (Supplementary Fig. 2). BAPTA/AM reduced the expression of all variables analyzed in the presence of $\mathrm{T}_{3}$, but did not have significant effects in control conditions (Fig. 8)

\section{Discussion}

The main findings of this study were that thyroid hormones stimulate L-arginine uptake and the mRNA expression of L-arginine transporters in HUVECs and that the thyroid hormone receptor on plasma membrane

\begin{tabular}{|lr} 
http://joe.endocrinology-journals.org & ○ 2018 Society for Endocrinology \\
https://doi.org/10.1530/JOE-18-0229 & Published by Bioscientifica Ltd. \\
Printed in Great Britain
\end{tabular}

integrin $\alpha v \beta 3$ plays an essential role in these effects. In HUVECs, L-arginine transport is mediated by the CAT isoforms $y^{+} /$CAT-1 (Sobrevia et al. 1995, Flores et al. 2003), $\mathrm{y}^{+} /$CAT-2b (Casanello \& Sobrevia 2002) and systems $\mathrm{b}^{0,+}$ (Bussolati et al. 1993) and $\mathrm{y}^{+} \mathrm{L}$ (Arancibia-Garavilla et al. 2003). All these transport systems except for CAT2b were upregulated by thyroid hormones. In fact, it has been reported that CAT-2b expression is only stimulated under cytokine or lipopolysaccharide treatment (Simmons et al. 1996). In the present study, $T_{3}$ and its analog TRIAC were the most active hormones in increasing mRNA of L-arginine $\mathrm{Na}^{+}$-independent and -dependent transporters after $6 \mathrm{~h}$. It is likely that $6 \mathrm{~h}$ is the optimal period for the full development of intracellular signaling. The effects on the different L-arginine transport systems were similar between TRIAC and $\mathrm{T}_{3}$, in consonance with previous data showing that TRIAC and $\mathrm{T}_{3}$ inhibit leptin secretion 

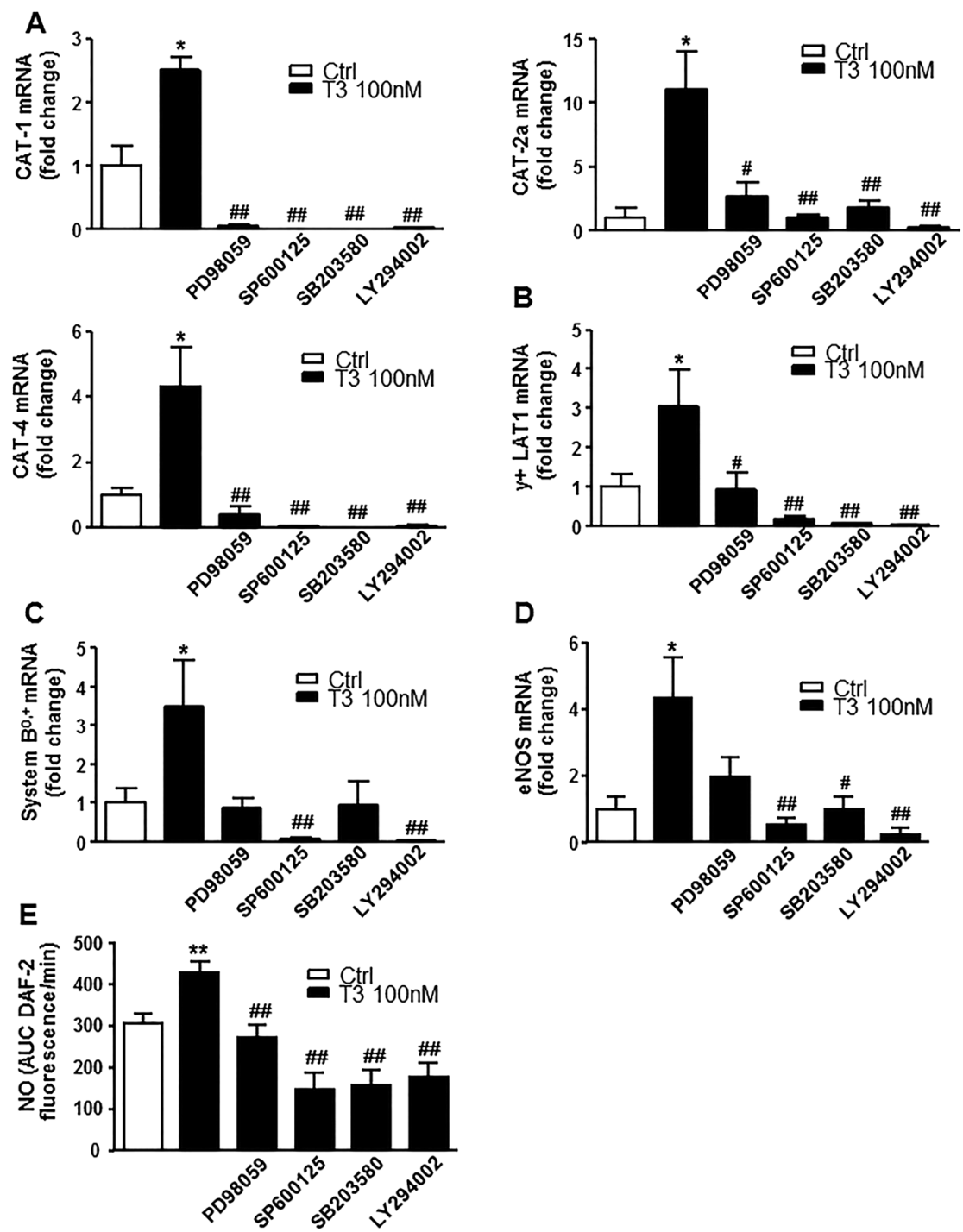

Effects of PI3K, MAPK and inhibitors on L-arginine transporters and NO production stimulated by $T_{3}$ $(100 \mathrm{nM})$. Cultures were incubated for the indicated times in the presence of $T_{3}$ at concentrations of $100 \mathrm{nM}$ in the absence or presence of the following inhibitors: LY-294002 for PI3K, PD98059 for ERK1/2, SP600125 for JNK, SB203580 for p38 MAPK. The inhibitors were added $1 \mathrm{~h}$ before $\mathrm{T}_{3}$ administration. mRNA levels of CAT-1, CAT-2a, CAT-4 (A), $y+$ LAT1 (B), system $\mathrm{B}^{0,+}(\mathrm{C})$, and eNOS (D) and A23187-stimulated NO production (E). ${ }^{*} P<0.05, * * P<0.01$ vs control (Ctrl) levels; $\# P<0.05, \# P<0.01$ vs without inhibitor.

with similar potency (Medina-Gómez et al. 2004). TRIAC exerts thyromimetic actions on the hypothalamuspituitary-thyroid axis and on peripheral tissues including brain, heart, bone, liver, kidney, adipose tissue and skin, but its exact physiological role is unknown (Groeneweg et al. 2017). TRIAC binds efficiently to nuclear TRs (Oppenheimer et al. 1973, Smith et al. 1980), with a similar affinity as $\mathrm{T}_{3}$ to $\mathrm{TR} \alpha 1$ and a 3- to 6-fold higher affinity than $\mathrm{T}_{3}$ to TR $\beta 1$ and TR $\beta 2$ (Schueler et al. 1990, Messier \& Langlois 2000); and the present data indicate that TRIAC binds to the integrin $\alpha \mathrm{v} \beta 3$ plasma membrane receptor in endothelial cells, as reported D'Arezzo et al. (2004) in L-6 myoblasts.

Although the more active concentration of $\mathrm{T}_{3}$ $(100 \mathrm{nM})$ is higher than physiological plasma levels ( $\sim 6$ fold), it should be taken into account that $\mathrm{T}_{4}$ is supplied to cells at micromolar range and is transformed into $\mathrm{T}_{3}$ by iodothyronine deiodinases. Thus, it has been reported that deiodinase 1 is present in endothelial cells (Sabatino et al. 2015). Deiodinase 1 transforms $\mathrm{T}_{4}$ into $\mathrm{T}_{3}$, releasing $\mathrm{T}_{3}$ to the plasma, being responsible for the $80 \%$ of the plasma levels of $T_{3}$. This process of release might generate high levels of $\mathrm{T}_{3}$ around the plasma membrane. Moreover, Bergh et al. (2005) reported that cultures incubated with $100 \mathrm{nM}$ total $\mathrm{T}_{4}$ result in $1-0.1 \mathrm{nM}$ free $\mathrm{T}_{4}$, consistent with normal physiological levels. Hence, the data reported here can be considered of physiological relevance, playing a greater role in the hyperthyroid state.

Endothelial synthesis of $\mathrm{NO}$ requires the de novo import of extracellular L-arginine, and a correlation was found between $\mathrm{NO}$ production and L-arginine transport (Arancibia-Garavilla et al. 2003, Kakoki et al. 2004). The $\mathrm{y}^{+} /$CATs system is the principal cationic amino acid transport system for regulating the intracellular supply 
A
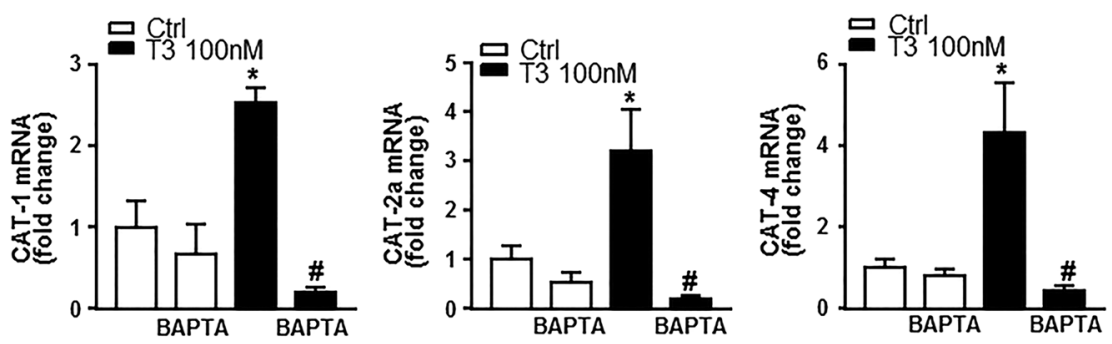

\section{Figure 8}

Effects intracellular $\mathrm{Ca}^{2+}$ chelation on L-arginine transporters and NO production stimulated by $\mathrm{T}_{3}$
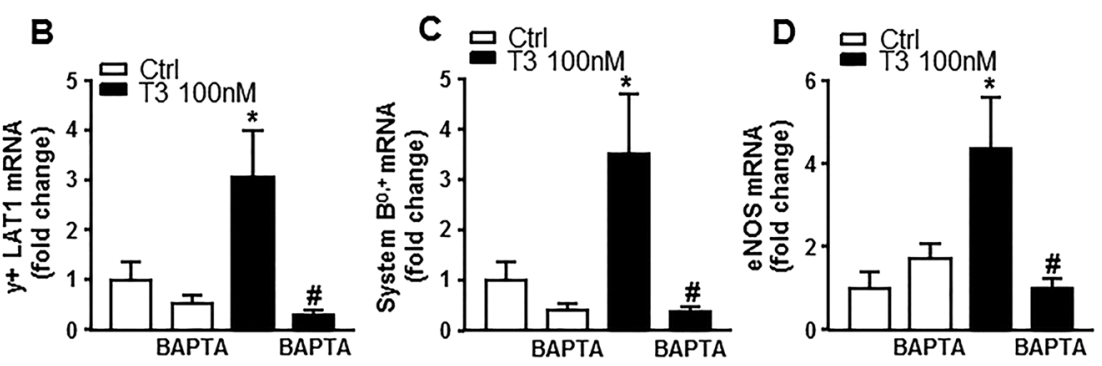
$(100 \mathrm{nM})$. Cultures were incubated for the indicated times in the presence $T_{3}$ at concentrations of $100 \mathrm{nM}$ in the absence or presence of BAPTA/AM for intracellular $\mathrm{Ca}^{2+}$ chelation. BAPTA/AM was added $1 \mathrm{~h}$ before $\mathrm{T}_{3}$ administration and was also studied in the absence of $T_{3}$. mRNA levels of CAT-1, CAT-2a, CAT-4 (A), $\mathrm{y}^{+}$LAT1 (B), system $\mathrm{B}^{0,+}(\mathrm{C})$, and eNOS (D) and A23187 stimulated NO production (E). ${ }^{*} P<0.05, * * P<0.01$ vs control (Ctrl) levels; $\# P<0.05, \# P<0.01$ vs without inhibitor.

of L-arginine for NOS, and $\mathrm{y}^{+} /$CATs activity may be rate limiting for NO synthesis. In addition, human umbilical vein endothelium also requires the activity of the cationic and neutral amino acid transport system $\mathrm{y}^{+} \mathrm{L}$ for $\mathrm{NO}$ synthesis (Arancibia-Garavilla et al. 2003). After observing that L-arginine uptake and both $\mathrm{y}^{+} / \mathrm{CAT}$ and $\mathrm{y}^{+} \mathrm{L}$ systems were stimulated by thyroid hormone, we investigated the effects of $\mathrm{T}_{3}, \mathrm{~T}_{4}$ and TRIAC on eNOS mRNA expression and NO production, finding that both classic thyroid hormones and TRIAC stimulated eNOS mRNA expression and NO generation in HUVECs. These last results are in agreement with previous reports of the enhancement by $\mathrm{T}_{3}$ of $\mathrm{NO}$ production in vascular myocytes and the expression of all three NOS isoforms (Carrillo-Sepulveda et al. 2010) and of the stimulation by $\mathrm{T}_{3}$ of eNOS activity in endothelial cells (Hiroi et al. 2006). The present study reports for the first time that eNOS mRNA and NO production were also stimulated by TRIAC.

Recently, Flamant et al. (2017) have defined four types of thyroid hormone signaling. The classical genomic actions exerted by binding of $\mathrm{T}_{3}$ to high-affinity nuclear thyroid hormone receptors (TRs) to regulate gene expression (Brent 1994) is now called type 1 of thyroid hormone action. By this type of signaling, thyroid hormones play important roles in metabolism, growth and cell differentiation (Lazar 1993). When thyroid hormone interacts with TRs and does not require direct interaction with DNA, it is called type 2 or 3 of thyroid hormone action. Thus, $\mathrm{T}_{3}$ can also bind to cytoplasmic (Vicinanza et al. 2013) and membrane-localized (Kalyanaraman et al. 2014) TRs, which interact with intracellular signaling pathways. Finally, the type 4 way of signaling is when $\mathrm{TH}$ acts independently of TRs, binding to other types of proteins. This type of thyroid hormone action can be included to the effects mediated by the binding of TTHH with the plasma membrane integrin $\alpha v \beta 3$ that contains a cell-surface receptor for thyroid hormones. $\mathrm{T}_{4}$ and $\mathrm{T}_{3}$ activate this receptor without entering the cell (Bergh et al. 2005). This integrin $\alpha v \beta 3$ receptor mediates a set of short- and long-term effects of thyroid hormone on membrane ion pumps and amino acids and an array of genes modulated by thyroid hormone (Davis et al. 2016). We studied whether this membrane receptor plays a role in increasing L-arginine uptake, the mRNA expression of L-arginine transporters, eNOS mRNA and the production of NO by thyroid hormones. Our results demonstrate that pharmacological blockade of integrin $\alpha v \beta 3$ by TETRAC suppressed the stimulatory effects of natural thyroid hormones and TRIAC on these variables. These observations were further verified by analyzing the effects of the genetic blockade of $\alpha \mathrm{v}$ integrin, which confirmed the results obtained by pharmacological blockade of $\alpha v \beta 3$ with TETRAC. All these findings demonstrate the participation of integrin $\alpha v \beta 3$, mainly $\alpha$ v subunit, in these stimulatory effects of thyroid hormones.

We explored the participation of PI3K, MAPK and intracellular calcium in the signaling pathways of the stimulatory effects of thyroid hormones on L-arginine transporters and eNOS mRNA and NO. Results indicate that these intracellular pathways participate in these effects. These findings are consistent with the involvement of PI3K, MAPK and intracellular calcium 


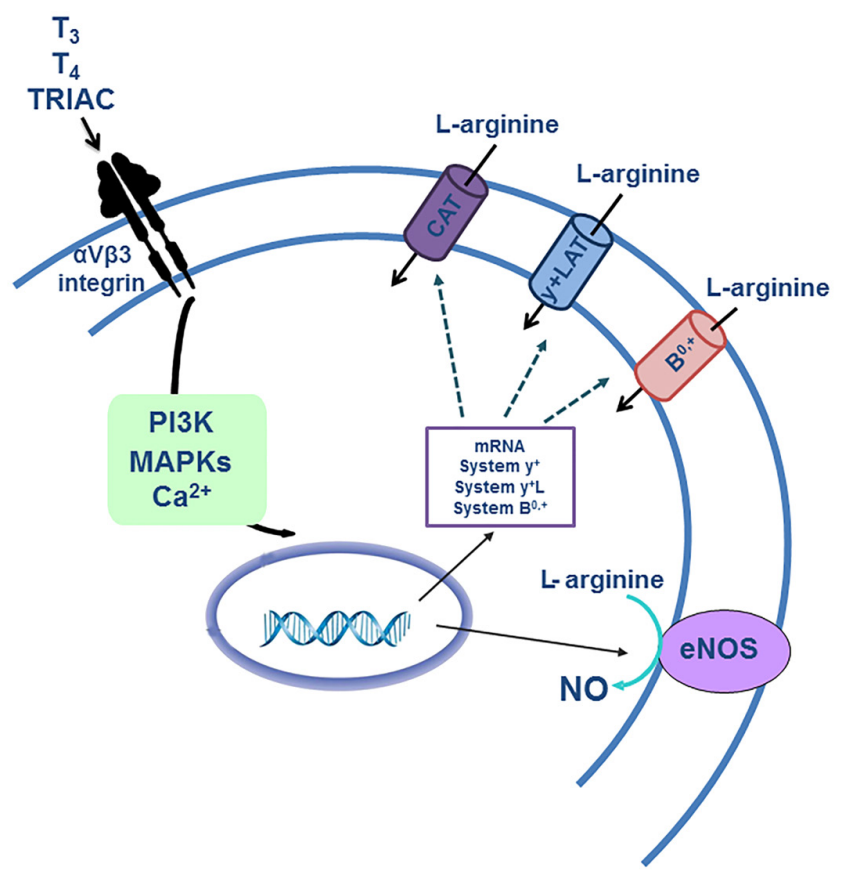

Figure 9

Proposed model for the sequence of events initiated by thyroid hormones in the plasma membrane that modify L-arginine transport in HUVECs. Scheme showing the proposed mechanisms underlying the stimulatory effects of thyroid hormones on sodium-dependent and -independent L-arginine transporters and eNOS in HUVECs. $\alpha \mathrm{V} \beta 3$ integrin and PI3K, MAPK and intracellular $\mathrm{Ca}^{2+}$ signaling are critical steps in these effects of thyroid hormones. The binding of thyroid hormones to integrin $\alpha \vee \beta 3$ activates PI3K, MAPK and intracellular $\mathrm{Ca}^{2+}$, which increased mRNA expression of $\mathrm{L}$-arginine transporters, with subsequent $\mathrm{L}$-arginine uptake and NO production. A full color version of this figure is available at https://doi.org/10.1530/JOE-18-0229.

in other effects of thyroid hormones on membrane transport systems in different cells. Thus, Na, K-ATPase and NHE1 ion transporter (D'Arezzo et al. 2004) and amino acid transport system A (Incerpi et al. 2002) were activated via a transduction pathway involving PKC, PI3K, the MAPKs and intracellular calcium (Incerpi et al. 2002, D'Arezzo et al. 2004). In addition, integrin $\alpha v ß 3$ is linked to the activation of MAPKs (Bergh et al. 2005), and TETRAC blocks these hormonal actions, which are downstream from MAPKs (Yalcin et al. 2010). Accordingly, these factors may be sequential steps in the stimulatory effects of thyroid hormones on L-arginine transporters' upregulation. Finally, a schematic outline summarizing the sequence of events initiated by thyroid hormones in the plasma membrane is shown in Fig. 9. The cell-surface hormone signal is initiated at $\alpha v \beta 3$ integrin receptor and transduced through stimulation of PI3K, MAPKs (ERK1/2, JNK and p38) and intracellular calcium, culminating in the increased mRNA levels of the L-arginine transporter and of eNOS. Moreover, the present results suggest that the continuous release of thyroid hormones, modulating L-arginine transporter activity, may contribute to the basal endothelial production of $\mathrm{NO}$ and vascular tone under physiological conditions; hence, alterations of this mechanism may participate in the cardiovascular abnormalities of thyroid disorders.

In conclusion, this paper shows for the first time that thyroid hormones stimulate L-arginine $\mathrm{Na}^{+}$-dependent and -independent transporters and potentiate the NO production induced by calcium ionophore. These effects are blocked by pharmacological $\alpha v \beta 3$ integrin inhibition or genetic $\alpha \mathrm{V}$ subunit downregulation or by PI3K, MAPK or intracellular calcium signaling inhibitors, indicating the key role of these mechanisms.

\section{Supplementary data}

This is linked to the online version of the paper at https://doi.org/10.1530/ JOE-18-0229.

\section{Declaration of interest}

The authors declare that there is no conflict of interest that could be perceived as prejudicing the impartiality of the research reported.

\section{Funding}

This study was supported by a grant (CTS-6704, CTS-251, CTS-164, P12-CTS-2722) from the Junta de Andalucía and from the Carlos III Health Institute of the Spanish Ministry of Health and Consumer Affairs (Red de Investigación Renal, REDinREN 012/0021). 'FEDER una manera de hacer Europa'.

\section{Acknowledgments}

The authors are grateful to R Davies for help with the English version.

\section{References}

Arancibia-Garavilla Y, Toledo F, Casanello P \& Sobrevia L 2003 Nitric oxide synthesis requires activity of the cationic and neutral amino acid transport system $\mathrm{y}^{+} \mathrm{L}$ in human umbilical vein endothelium. Experimental Physiology 88 699-710. (https://doi.org/10.1113/ eph8802647)

Bergh JJ, Lin HY, Lansing L, Mohamed SN, Davis FB, Mousa S \& Davis PJ 2005 Integrin $\alpha v ß 3$ contains a cell surface receptor site for thyroid hormone that is linked to activation of mitogen-activated protein kinase and induction of angiogenesis. Endocrinology 146 2864-2871. (https://doi.org/10.1210/en.2005-0102)

Block E, Herrera H \& Couch M 1995 Hypoxia inhibits L-arginine uptake by pulmonary artery endothelial cells. American Journal of Physiology 269 L574-L580. (https://doi.org/10.1152/ajplung.1995.269.5.L574)

Bogle RG, Coade SB, Moncada S, Pearson JD \& Mann GE 1991 Bradykinin and ATP stimulate L-arginine uptake and nitric oxide release in 
vascular endothelial cells. Biochemical and Biophysical Research Communications 180 926-932. (https://doi.org/10.1016/S0006291X(05)81154-4)

Brent GA 1994 The molecular basis of thyroid hormone action. New England Journal of Medicine 331 847-853. (https://doi.org/10.1056/ NEJM199409293311306)

Bussolati O, Sala R, Astorri A, Rotoli B, Dall'Asta MV \& Gazzola GC 1993 Characterization of amino acid transport in human endothelial cells. American Journal of Physiology 265 1006-1014. (https://doi. org/10.1152/ajpcell.1993.265.4.C1006)

Carrillo-Sepulveda MA, Ceravolo GS, Fortes ZB, Laurindo FR, Webb RC \& Barreto-Chaves ML 2010 Thyroid hormone stimulates NO production via activation of the PI3K/Akt pathway in vascular myocytes. Cardiovascular Research 85 560-570. (https://doi.org/10.1093/cvr/ cvp304)

Casanello P \& Sobrevia L 2002 Intrauterine growth retardation is associated with reduced activity and expression of the cationic amino acid transport systems $\mathrm{y}^{+} / \mathrm{hCAT}-1$ and $\mathrm{y}^{+} / \mathrm{hCAT}-2 \mathrm{~B}$ and lower activity of nitric oxide synthase in human umbilical veinendothelial cells. Circulation Research 91 127-134. (https://doi.org/10.1161/01. RES.0000027813.55750.E7

Casanello P, Krause B, Torres E, Gallardo V, González M, Prieto C, Escudero C Farías M \& Sobrevia ML 2009 Reduced L-arginine transport and nitric oxide synthesis in human umbilical vein endothelial cells from intrauterine growth restriction pregnancies is not further altered by hypoxia. Placenta 30 625-633. (https://doi. org/10.1016/j.placenta.2009.04.010)

Chen Y \& Sanders PW 1991 L-arginine abrogates salt-sensitive hypertension in dahl/rapp rats. Journal of Clinical Investigation $\mathbf{8 8}$ 1559-1567. (https://doi.org/10.1172/JCI115467)

Closs EI 2002 Expression, regulation and function of carrier proteins for cationic amino acids. Current Opinion in Nephrology and Hypertension 11 99-107. (https://doi.org/10.1097/00041552-200201000-00015)

Creager MA, Cooke JP, Mendelsohn ME, Gallagher SJ, Coleman SM, Loscalzo J \& Dzau VJ 1990 Impaired vasodilation of forearm resistance vessels in hypercholesterolemic humans. Journal of Clinical Investigation 86 228-234. (https://doi.org/10.1172/JCI114688)

D'Arezzo S, Incerpi S, Davis FB, Acconcia F, Marino M, Farias RN \& Davis PJ 2004 Rapid nongenomic effects of 3,5,3'-triiodo-L-thyronine on the intracellular $\mathrm{pH}$ of L-6 myoblasts are mediated by intracellular calcium mobilization and kinase pathways. Endocrinology 145 5694-5703. (https://doi.org/10.1210/en.2004-0890)

Davis PJ, Goglia F \& Leonard JL 2016 Nongenomic actions of thyroid hormone. Nature Reviews Endocrinology 12 111-121. (https://doi org/10.1038/nrendo.2015.205)

Flamant F, Cheng S-Y, Hollenberg AN, Moeller LC, Samarut J, Wondisford FE, Yen PM \& Refetoff S 2017 Thyroid hormone signaling pathways: time for a more precise nomenclature. Endocrinology 158 2052-2057. (https://doi.org/10.1210/en.2017-00250)

Flores C, Rojas S, Aguayo C, Parodi J, Mann G, Pearson JD, Casanello P \& Sobrevia L 2003 Rapid stimulation of L-arginine transport by D-glucose involves p42/44mapk and nitric oxide in human umbilical vein endothelium. Circulation Research 92 64-72. (https://doi. org/10.1161/01.RES.0000048197.78764.D6)

González M, Gallardo V, Rodríguez N, Salomón C, Westermeier F, Guzmán Gutiérrez E, Abarzúa F, Leiva A, Casanello P \& Sobrevia L 2011 Insulin-stimulated L-arginine transport requires SLC7A1 gene expression and is associated with human umbilical vein relaxation. Journal of Cellular Physiology 226 2916-2924. (https://doi.org/10.1002/ jcp.22635)

Groeneweg S, Peeters RP, Visser TJ \& Visser WE 2017 Triiodothyroacetic acid in health and disease. Journal of Endocrinology 234 R99-R121 (https://doi.org/10.1530/JOE-17-0113)

Grupper A, Shashar M, Bahry D, Pri-Paz Y, Ben Tur O, Levi S, Chernichovski T, Chernin G \& Schwartz IF 2013 Cyclosporine attenuates arginine transport, in human endothelial cells, through modulation of cationic amino acid transporter-1. American Journal of Nephrology 37 613-619. (https://doi. org/10.1159/000350614)

Harrison DG 1991 Endothelial modulation of vascular tone: relevance to coronary angioplasty and restenosis. Journal of the American College of Cardiology 17 71-76. (https://doi.org/10.1016/0735-1097(91)90941-2)

Hiroi Y, Kim HH, Ying H, Furuya F, Huang Z, Simoncini T, Noma K, Ueki K, Nguyen NH, Scanlan TS, et al. 2006 Rapid nongenomic actions of thyroid hormone. PNAS 103 14104-14109. (https://doi. org/10.1073/pnas.0601600103)

Incerpi S, De Vito P, Luly P, Spagnuolo S \& Leoni S 2002 Short-term effects of thyroid hormones and 3,5-diiodothyronine on membrane transport systems in chick embryo hepatocytes. Endocrinology 143 1660-1668. (https://doi.org/10.1210/endo.143.5.8767)

Jiménez R, Sánchez M, Zarzuelo MJ, Romero M, Quintela AM, LópezSepúlveda R, Galindo P, Gómez-Guzmán M, Haro JM, Zarzuelo A, et al. 2010 Endothelium-dependent vasodilator effects of peroxisome proliferator-activated receptor beta agonists via the phosphatidylinositol-3 kinase-Akt pathway. Journal of Pharmacology and Experimental Therapeutics 332 554-561. (https://doi.org/10.1124/ jpet.109.159806)

Kakoki M, Kim HS, Arendshorst WJ \& Mattson DL 2004 L-arginine uptake affects nitric oxideproduction and blood flow in the renal medulla. American Journal of Physiology: Regulatory, Integrative and Comparative Physiology 287 1478-1485. (https://doi.org/10.1152/ ajpregu.00386.2004)

Kalyanaraman H, Schwappacher R, Joshua J, Zhuang S, Scott BT, Klos M, Casteel DE, Frangos JA, Dillmann W, Boss GR et al. 2014 Nongenomic thyroid hormone signaling occurs through a plasma membranelocalized receptor. Science Signaling 7 ra48 (https://doi.org/10.1126/ scisignal.2004911)

Klein I 1990 Thyroid hormone and the cardiovascular system. American Journal of Medicine 88 631-637. (https://doi.org/10.1016/00029343(90)90531-H)

Lazar MA 1993 Thyroid hormones receptors: multiple forms, multiple possibilities. Endocrine Reviews 14 184-193. (https://doi.org/10.1210/ edrv-14-2-184)

Malakauskas SM, Quan H, Fields TA, McCall SJ, Yu MJ, Kourany WM, Frey CW \& Le TH 2007 Aminoaciduria and altered renal expression of luminal amino acid transporters in mice lacking novel gene collectrin. American Journal of Physiology: Renal Physiology 292 533-544. (https://doi.org/10.1152/ajprenal.00325.2006)

Mann GE, Yudilevich DL \& Sobrevia L 2003 Regulation of amino acid and glucose transporters in endothelial and smooth muscle cells. Physiological Reviews 83 183-252. (https://doi.org/10.1152/ physrev.00022.2002)

Martens CR, Kuczmarski JM, Lennon-Edwards S \& Edwards DG 2014 Impaired L-arginine uptake but not arginase contributes to endothelial dysfunction in rats with chronic kidney disease. Journal of Cardiovascular Pharmacology and Therapeutics 63 40-48. (https://doi. org/10.1097/FJC.0000000000000022)

McDonald KK, Zharidov S, Block ER \& Kilberg MS 1997 Acaveolar complex between the cationic amino acid transporter 1 and endothelial nitric oxide synthase may explain the 'arginine paradox'. Journal of Biological Chemistry 272 31213-31216. (https://doi. org/10.1074/jbc.272.50.31213)

Medina-Gómez G, Calvo RM \& Obregón MJ 2004 T 3 and Triac inhibit leptin secretion and expression in brown and white rat adipocytes. Biochimica et Biophysica Acta 1682. 38-47. (https://doi.org/10.1016/j. bbalip.2004.01.007)

Messier N \& Langlois MF 2000 Triac regulation of transcription is T(3) receptor isoform- and response element-specific. Molecular and Cellular Endocrinology 165 57-66. (https://doi.org/10.1016/S03037207(00)00266-5)

Moreno JM, Rodríguez-Gómez I, Wangensteen R, Osuna A, Bueno P \& Vargas F 2005 Cardiac and renal antioxidant enzymes and effects (c) 2018 Society for Endocrinology Published by Bioscientifica Ltd. Printed in Great Britain 
of tempol in hyperthyroid rats. American Journal of Physiology: Endocrinology and Metabolism 289 776-783. (https://doi.org/10.1152/ ajpendo.00611.2004)

Ogonowski AA, Kaesemeyer WH, Jin L, Ganapathy V, Leibach FH \& Caldwell RW 2000 Effects of NO donors and synthase agonists on endothelial cell uptake of L-arg and superoxide production. American Journal of Physiology 278 136-143. (https://doi.org/10.1152/ ajpcell.2000.278.1.C136)

Oppenheimer JH, Schwartz HL, Dillman W \& Surks MI 1973 Effect of thyroid hormone analogues on the displacement of 125I-Ltriiodothyronine from hepatic and heart nuclei in vivo: possible relationship to hormonal activity. Biochemical and Biophysical Research Communications 55 544-550. (https://doi.org/10.1016/0006291X(73)91177-7)

Pallone TL \& Mattson DL 2002 Role of nitric oxide in regulation of the renal medulla in normal and hypertensive kidneys. Current Opinion in Nephrology and Hypertension 11 93-98. (https://doi. org/10.1097/00041552-200201000-00014)

Patel JM, Abeles AJ \& Block ER 1996 Nitric oxide exposure and sulfhydryl modulation alter L-arginine transport in cultured pulmonary artery endothelial cells. Free Radical Biology and Medicine 20 629-637. (https://doi.org/10.1016/0891-5849(95)02146-9)

Quesada A, Sainz J, Wangensteen R, Rodriguez-Gomez I, Vargas F \& Osuna A 2002 Nitric oxide synthase activity in hyperthyroid and hypothyroid rats. European Journal of Endocrinology 147 117-122. (https://doi.org/10.1530/eje.0.1470117)

Quintela AM, Jiménez R, Piqueras L, Gómez-Guzmán M, Haro J, Zarzuelo MJ, Cogolludo A, Sanz MJ, Toral M, Romero M, et al. 2014 PPAR $\beta$ activation restores the high glucose-induced impairment of insulin signalling in endothelial cells. British Journal of Pharmacology 171 3089-3102. (https://doi.org/10.1111/bph.12646)

Rajapakse NW, Karim F, Straznicky NE, Fernandez S, Evans RG, Head GA \& Kaye DM 2014 Augmented endothelial-specific L-arginine transport prevents obesity-induced hypertension. Acta Physiology 212 39-48. (https://doi.org/10.1111/apha.12344)

Rodríguez-Gómez I, Sainz J, Wangensteen R, Moreno JM, Duarte J, Osuna A \& Vargas F 2003 Increased pressor sensitivity to chronic nitric oxide deficiency in hyperthyroid rats. Hypertension 42 220-225. (https://doi.org/10.1161/01.HYP.0000081944.47230.69)

Rodríguez-Gómez I, Wangensteen R, Moreno JM, Chamorro V, Osuna A \& Vargas F 2005 Effects of chronic inhibition of inducible nitric oxide synthase in hyperthyroid rats. American Journal of Physiology: Endocrinology and Metabolism 288 1252-1257. (https://doi. org/10.1152/ajpendo.00279.2004)

Rodríguez-Gómez I, Manuel Moreno J, Jimenez R, Quesada A, MontoroMolina S, Vargas-Tendero P, Wangensteen R \& Vargas F 2015 Effects of arginase inhibition in hypertensive hyperthyroid rats. American Journal of Hypertension 28 1464-1472. (https://doi.org/10.1093/ajh/ hpv049)

Rodríguez-Gómez I, Moliz JN, Quesada A, Montoro-Molina S, VargasTendero P, Osuna A, Wangensteen R \& Vargas F 2016 L-arginine metabolism in cardiovascular and renal tissue from hyper- and hypothyroid rats. Experimental Biology and Medicine 241 550-556. (https://doi.org/10.1177/1535370215619042)

Sabatino L, Lubrano V, Balzan S, Kusmic C, Del Turco S, \& Iervasi G 2015 Thyroid hormone deiodinases D1, D2, and D3 are expressed in human endothelial dermal microvascular line: effects of thyroid hormones. Molecular and Cellular Biochemistry 399 87-94. (https://doi. org/10.1007/s11010-014-2235-8)
Schueler PA, Schwartz HL, Strait KA, Mariash CN \& Oppenheimer JH 1990 Binding T3 and its analogs to the in vitro translational products of c-erb A protooncogenes: differences in the affinity of the $\alpha$ - and $\beta$-forms for the acetic acid analog and failure of the human testis and kidney-2 products to bind $\mathrm{T}_{3}$. Molecular Endocrinology 4 227-234. (https://doi.org/10.1210/mend-4-2-227)

Schwartz IF, Schwartz D, Traskonov M, Chernichovsky T, Wollman Y, Gnessin E, Topilsky I, Levo Y \& Iaina A 2002 L-arginine transport is augmented through up-regulation of tubular CAT-2 mRNA in ischemic acute renal failure in rats. Kidney International 62 1700-1706. (https://doi.org/10.1046/j.1523-1755.2002.t01-1-00622.x)

Simmons WW, Closs EI, Cunningham JM, Smith TW \& Kelly RA 1996 Cytokines and insulin induce cationic amino acid transporter (CAT) expression in cardiac myocytes. Regulation of $\mathrm{L}$-arginine transport and NO production by CAT-1, CAT-2A, and CAT-2B. Journal of Biological Chemistry 271 11694-11702. (https://doi.org/10.1074/ jbc.271.20.11694)

Smith HC, Robinson SE \& Eastman CJ 1980 Binding of endogenous iodothyronines to isolated liver cell nuclei. Endocrinology 106 1133-1136. (https://doi.org/10.1210/endo-106-4-1133)

Sobrevia L, Cesare P, Yudilevich DL \& Mann GE 1995 Diabetes induced activation of system $\mathrm{y}^{+}$and nitric oxide synthase in human endothelial cells: association with membrane hyperpolarization. Journal of Physiology 489 183-192. (https://doi.org/10.1113/ jphysiol.1995.sp021040)

Vargas F, Fernandez-Rivas A, García-Estañ J \& Garcia del Rio C 1995 Endothelium-dependent and endothelium-independent vasodilation in hyperthyroid and hypothyroid rats. Pharmacology 51 308-314. (https://doi.org/10.1159/000139340)

Vargas F, Moreno JM, Rodríguez-Gómez I, Wangensteen R, AlvarezGuerra M, Osuna A \& García-Estañ J 2006 Vascular and renal function in experimental thyroid disorders. European Journal of Endocrinology 154 1-17. (https://doi.org/10.1530/eje.1.02062)

Verrey F, Closs EI, Wagner CA, Palacin M, Endou H \& Kanai Y 2004 CATs and HATs: the SLC7family of amino acid transporters. Pflügers Archiv: European Journal of Physiology 447 532-542. (https://doi.org/10.1007/ s00424-003-1086-z)

Vicinanza R, Coppotelli G, Malacrino C, Nardo T, Buchetti B, Lenti L, Celi FS \& Scarpa S 2013 Oxidized low-density lipoproteins impair endothelial function by inhibiting non-genomic action of thyroid hormone- mediated nitric oxide production in human endothelial cells. Thyroid 23 231-238. (https://doi.org/10.1089/thy.2011.0524)

Wascher TC, Graier WF, Dittrich P, Hussain MA, Bahadori B, Wallner S \& Toplak H 1997 Effects of low-dose L-arginine on insulinmediated vasodilation and insulin sensitivity. European Journal of Clinical Investigation 27 690-695. (https://doi.org/10.1046/j.13652362.1997.1730718.x)

Weyrich AS, Ma X \& Lefer AM 1992 The role of L-arginine in ameliorating reperfusion injury after myocardial ischemia in the cat. Circulation 86 279-288. (https://doi.org/10.1161/01.CIR.86.1.279)

Yalcin M, Dyskin E, Lansing L, Bharali DJ, Mousa SS, Bridoux A, Hercbergs AH, Lin HY, Davis FB, Glinsky GV, et al. 2010 Tetraiodothyroaceticacid (Tetrac) and nanoparticula tetrac arrest growth of medullary carcinoma of the thyroid. Journal of Clinical Endocrinology and Metabolism 95 1972-1980. (https://doi.org/10.1210/jc.2009-1926)

Zharikov SI, Herrera H \& Block ER 1997 Role of membrane potential in hypoxic inhibition of L-arginine uptake by lung endothelial cells. American Journal of Physiology: Lung Cellular and Molecular Physiology 272 78-84. (https://doi.org/10.1152/ajplung.1997.272.1.L78)

Received in final form 4 July 2018

Accepted 17 July 2018

Accepted Preprint published online 18 July 2018 http://joe.endocrinology-journals.org https://doi.org/10.1530/JOE-18-0229 (c) 2018 Society for Endocrinology Published by Bioscientifica Ltd. Printed in Great Britain 